August 23, 2012

Ms. Donna Perez

ARRA Portfolio Manager

U.S. Department of Energy

Oak Ridge Office

P.O. Box 2001

Oak Ridge, TN 37831-0117

DOE CONTRACT NO. DE-AC05-060R23100

\title{
SUBJECT: SURVEY REPORT FOR THE CHARACTERIZATION OF THE FIVE \\ TANKS LOCATED NEAR THE OLD SALVAGE YARD AT THE Y-12 NATIONAL SECURITY COMPLEX, OAK RIDGE, TENNESSEE DCN: 5070-SR-01-0
}

Dear Ms. Perez:

Oak Ridge Associated Universities (ORAU), managing the Oak Ridge Institute for Science and Education (ORISE) contract, is pleased to provide this final report summarizing characterization activities for the Five Tanks located near the Old Salvage Yard (OSY) at the Y-12 National Security Complex in Oak Ridge, Tennessee. This report includes the final validated dataset and updates associated with the Tank 2 residues originally thought to be a biological bloom (e.g., slime mold) but ultimately identified as iron sulfate crystals.

Please contact me via the information listed below, or David King at 865.574.0685, if you have any questions or require additional information.

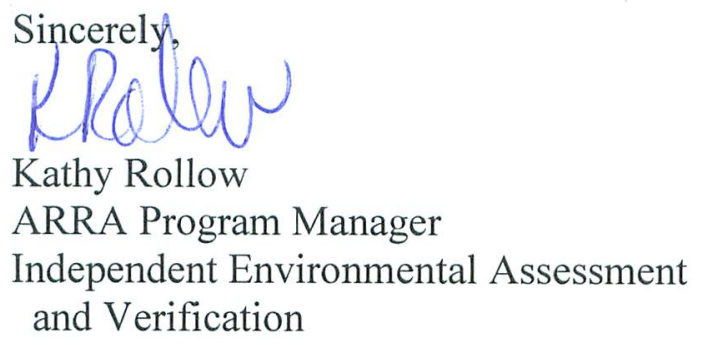

$\mathrm{KR} / \mathrm{fr}$

Enclosure

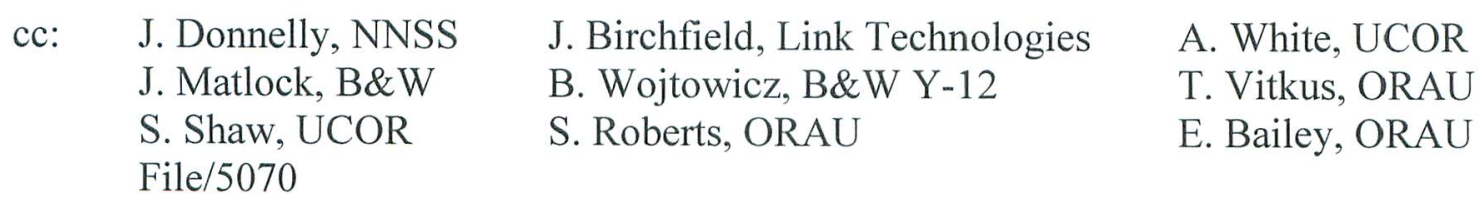

\begin{tabular}{|l|c|}
\hline Distribution approval and concurrence: & Initials \\
\hline Technical Review & \\
\hline Laboratory Review & \\
\hline Quality Review & \\
\hline Group Manager Review & $6 N B$ \\
\hline
\end{tabular}




\section{SURVEY REPORT FOR THE CHARACTERIZATION OF THE FIVE TANKS LOCATED NEAR THE OLD SALVAGE YARD AT THE Y-12 NATIONAL SECURITY COMPLEX, OAK RIDGE, TENNESSEE}

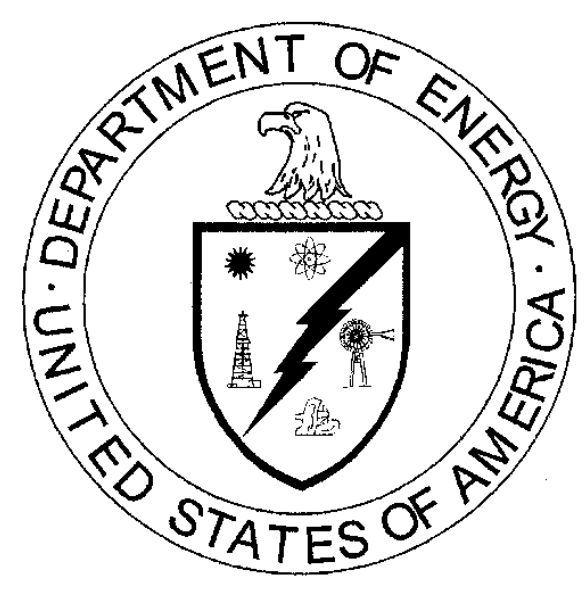

This document is approved for public release per review by:

Larry Sparks

July 24, 2012

Public Information Officer

Date

DOE/ORR Office of Public Affairs 
THIS PAGE LEFT INTENTIONALLY BLANK 


\section{SURVEY REPORT FOR THE CHARACTERIZATION OF THE FIVE TANKS LOCATED NEAR THE OLD SALVAGE YARD AT THE Y-12 NATIONAL SECURITY COMPLEX, OAK RIDGE, TENNESSEE}

This summary report presents analytical results, radiological survey data, and other data/information for disposition planning of the five tanks located west of the Old Salvage Yard (OSY) at the Y-12 National Security Complex (Y-12) in Oak Ridge, Tennessee. Field personnel from Oak Ridge Associated Universities (ORAU) and URS | CH2M Oak Ridge LLC completed data collection in May 2012 per the project-specific plan (PSP) (ORAU 2012). Deviations from the PSP are addressed in the body of this report.

Characterization activities included three data collection modes: visual inspection, radiological survey, and volumetric sampling/analysis. Table 1 summarizes results of the visual inspection; Table 2 summarizes results of the radiological survey; and Table 3 summarizes volumetric sampling activities. In the interest of completeness, additional screening results, including mercury and volatile organic vapor measurement information, are also presented in Table 1. Detailed data are provided on the attached compact disc and organized into three folders, as follows:

\section{FOLDER 1 - RAD SURVEY REPORTS}

The folder includes five Excel spreadsheets, one for each tank, with the following file names:

- Y-12 OSY RAD Survey Data Package - Tank 1.xls

- Y-12 OSY RAD Survey Data Package - Tank 2.xls

- $\quad$ Y-12 OSY RAD Survey Data Package - Tank 3.xls

- $\quad$ Y-12 OSY RAD Survey Data Package - Tank 4.xls

- $\quad$ Y-12 OSY RAD Survey Data Package - Tank 5.xls

Each spreadsheet contains the following three worksheets.

- "Direct Meas," which presents direct measurement results, including total and removable surface activity results in units of disintegrations per minute per $100 \mathrm{~cm}^{2}\left(\mathrm{dpm} / 100 \mathrm{~cm}^{2}\right)$ for comparison to applicable guidelines, which are also presented. All radiological survey measurements were collected using Ludlum model 43-68 detectors connected to Ludlum model 2221 ratemeter-scalers. Total activity and gross removable results are rounded to two significant digits.

- "Raw Scan Data," which presents a simple tabulation of the alpha-plus-beta $(\alpha+\beta)$ and alpha only $(\alpha)$ surface scan results in units of counts per minute (cpm). The scan data were collected using Ludlum model 43-68 detectors connected to Ludlum model 2221 ratemeter-scalers coupled to Trimble Recon data loggers.

- "Scan Charts," which presents summary statistics and Q-Q plots of the logged results from the "Raw Scan Data" worksheet. Note that the logged alpha measurements are based on extrapolated values, where 1-second counts are converted to cpm. For example, an instantaneous read-out of 1 count will 
be converted to $60 \mathrm{cpm}, 2$ counts converted to $120 \mathrm{cpm}$, etc. The objective of the plot is to illustrate significant deviations from the expected straight-line (normal) "curve." This phenomenon is not typically relevant for alpha-plus-beta measurements.

\section{FOLDER 2 - LABORATORY DATA}

The single Excel file contains the following four worksheets:

- "5 Tank Summary from PEMS," which presents data from the analytical laboratories uploaded to the Project Environmental Measurements System (PEMS), including results for residue, liner, and liquid samples collected during the May 2012 effort

- “Asbestos,” which presents asbestos analysis results of gaskets affixed to Tanks 3 and 4

- "Raschig Ring Composition," which presents the composition of the ring fragment collected from the south port of Tank 1

- "Solids Composition," which presents the composition of the yellow-green material collected from the base of Tank 2 and originally thought to be biological (e.g., slime mold)

NOTE: The complete PEMS analytical dataset is validated, but asbestos and composition data have not been validated.

\section{FOLDER 3 - DAILY FIELD}

This attachment includes the final string of daily e-mails that summarize field activities. 
Table 1. Visual inspection summary

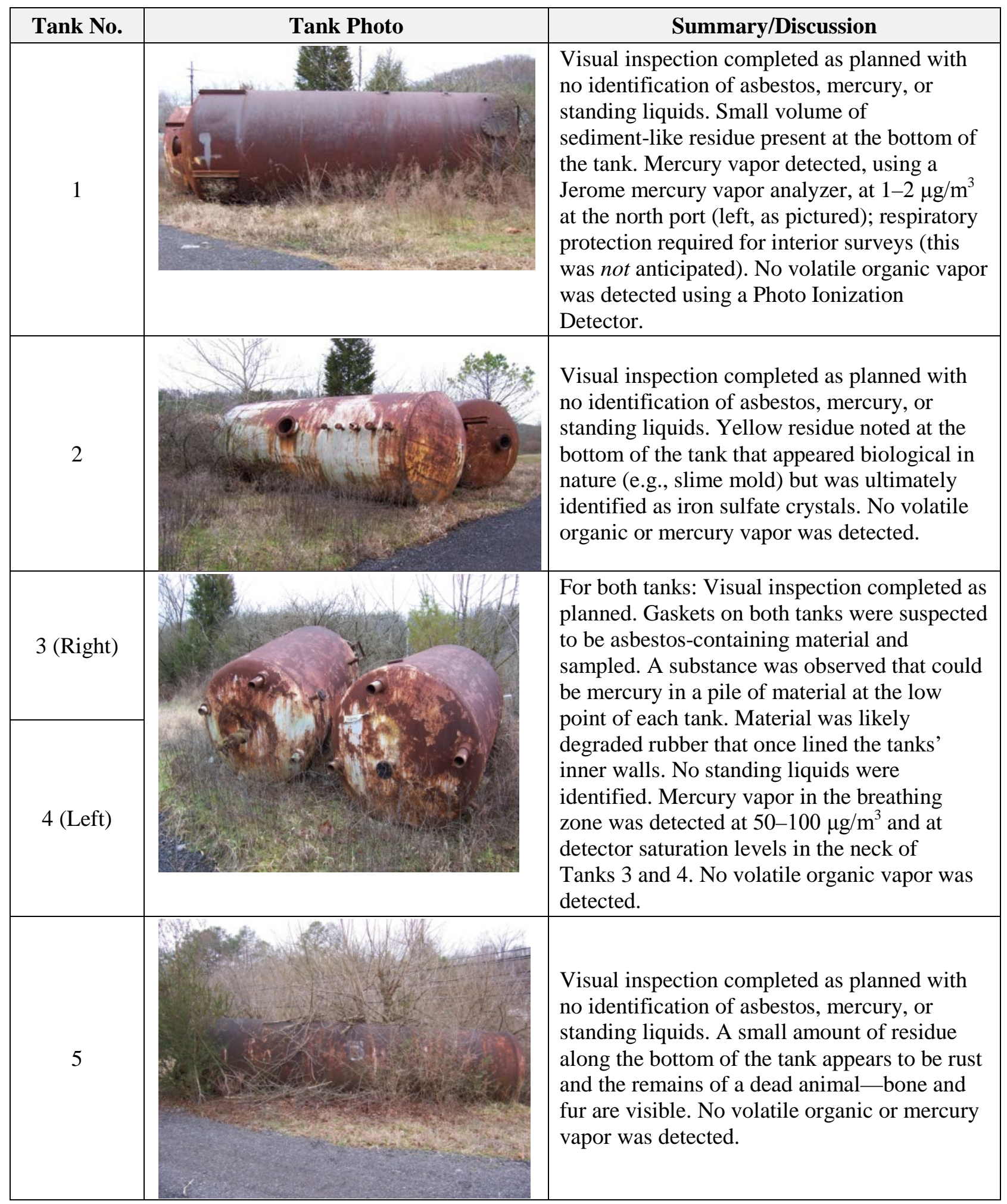


Table 2. Radiological survey summary

\begin{tabular}{|c|c|c|}
\hline Tank No. & Planned Activities & Completed Activities \\
\hline 1 & $\begin{array}{l}\text { Surface scans for alpha and alpha-plus-beta } \\
\text { activity on accessible interior and exterior } \\
\text { surfaces. Direct measurements for alpha and } \\
\text { alpha-plus-beta total and removable activity } \\
\text { at a total of } 15 \text { randomly-selected interior } \\
\text { and exterior locations. }\end{array}$ & $\begin{array}{l}\text { Exterior surveys were completed as planned. } \\
\text { Interior surface scan coverage was limited } \\
\text { and alternate direct measurement/smear } \\
\text { locations were used due to access limitations. } \\
\text { Technicians used probes attached to } \\
\text { extendable poles to cover as much interior } \\
\text { surface area as possible. } \\
\text { Slightly elevated radiation levels relative to } \\
\text { background detector responses were noted on } \\
\text { the rust covered tank exterior. The project } \\
\text { Radiological Control Technician, based on } \\
\text { prior unrelated experiences, speculated the } \\
\text { readings were due to radon. This is consistent } \\
\text { with the observed tendency of Po-210 (a } \\
\text { decay product of radon) to "stick" to metal } \\
\text { that is oxidized, rusty, or weathered } \\
\text { (Abelquist 2001). Based on this information, } \\
\text { elevated results are assumed attributable to } \\
\text { radon decay product and are not associated } \\
\text { with site-related radiological constituents. }\end{array}$ \\
\hline 2 & $\begin{array}{l}\text { Surface scans for alpha and alpha-plus-beta } \\
\text { activity on accessible interior and exterior } \\
\text { surfaces. Direct measurements for alpha and } \\
\text { alpha-plus-beta total and removable activity } \\
\text { at a total of } 15 \text { randomly-selected interior } \\
\text { and exterior locations. }\end{array}$ & $\begin{array}{l}\text { Exterior surveys were completed as planned. } \\
\text { Interior surface scan coverage was limited } \\
\text { and alternate direct measurement/smear } \\
\text { locations were used due to access limitations. } \\
\text { Technicians used probes attached to } \\
\text { extendable poles to cover as much interior } \\
\text { surface area as possible. } \\
\text { As with Tank 1, elevated results are assumed } \\
\text { attributable to radon decay product and are } \\
\text { not associated with site-related radiological } \\
\text { constituents. }\end{array}$ \\
\hline 3 & $\begin{array}{l}\text { Surface scans for alpha and alpha-plus-beta } \\
\text { activity on accessible interior and exterior } \\
\text { surfaces. Direct measurements for alpha and } \\
\text { alpha-plus-beta total and removable activity } \\
\text { at a total of } 15 \text { randomly-selected interior } \\
\text { and exterior locations. }\end{array}$ & $\begin{array}{l}\text { Exterior surveys were completed as planned. } \\
\text { Interior surveys could not be completed due } \\
\text { to high concentration of mercury vapor } \\
\text { emanating from the tank. Surveyors } \\
\text { ventilated the tank and area with fans, but } \\
\text { mercury vapor concentration exceeded the } \\
\text { protection factor of the air purifying } \\
\text { respirators (with mercury cartridges). } \\
\text { Self-contained breathing apparatuses would } \\
\text { be required to continue interior work on } \\
\text { Tanks } 3 \text { and } 4 \text {. } \\
\text { As with Tank 1, elevated results are assumed }\end{array}$ \\
\hline
\end{tabular}




\begin{tabular}{|c|c|c|}
\hline Tank No. & Planned Activities & Completed Activities \\
\hline & & $\begin{array}{l}\text { attributable to radon decay product and are } \\
\text { not associated with site-related radiological } \\
\text { constituents. }\end{array}$ \\
\hline 4 & $\begin{array}{l}\text { Surface scans for alpha and alpha-plus-beta } \\
\text { activity on accessible interior and exterior } \\
\text { surfaces. Direct measurements for alpha and } \\
\text { alpha-plus-beta total and removable activity } \\
\text { at a total of } 15 \text { randomly-selected interior } \\
\text { and exterior locations. }\end{array}$ & $\begin{array}{l}\text { Exterior surveys were completed as planned. } \\
\text { Interior surveys were not attempted based on } \\
\text { the mercury-vapor-related events } \\
\text { surrounding Tank } 3 \text { and considering worker } \\
\text { safety concerns. } \\
\text { As with Tank 1, elevated results are assumed } \\
\text { attributable to radon decay product and are } \\
\text { not associated with site-related radiological } \\
\text { constituents. }\end{array}$ \\
\hline 5 & $\begin{array}{l}\text { Surface scans for alpha and alpha-plus-beta } \\
\text { activity on accessible interior and exterior } \\
\text { surfaces. Direct measurements for alpha and } \\
\text { alpha-plus-beta total and removable activity } \\
\text { at a total of } 15 \text { randomly-selected interior } \\
\text { and exterior locations. }\end{array}$ & $\begin{array}{l}\text { Exterior surveys were completed as planned. } \\
\text { Interior surface scan coverage was limited } \\
\text { and alternate direct measurement/smear } \\
\text { locations were used due to access limitations. } \\
\text { Technicians used probes attached to } \\
\text { extendable poles to cover as much interior } \\
\text { surface area as possible. } \\
\text { As with Tank 1, elevated results are assumed } \\
\text { attributable to radon decay product and are } \\
\text { not associated with site-related radiological } \\
\text { constituents. }\end{array}$ \\
\hline
\end{tabular}


Table 3. Liquid and/or solid-media sampling summary

\begin{tabular}{|c|c|c|}
\hline Tank No. & Planned Activities & Completed Activities \\
\hline 1 & $\begin{array}{l}\text { No sampling planned due to presumed } \\
\text { insufficient residue volume and low } \\
\text { likelihood of contamination. }\end{array}$ & $\begin{array}{l}\text { Jerome measurements detected mercury } \\
\text { vapor; thus, residues at the bottom of the } \\
\text { tank were sampled for full suite analysis }{ }^{a}- \\
\text { the residue sample contained visible } \\
\text { mercury. } \\
\text { The plastic bag covering the back (south, as } \\
\text { currently oriented) tank port had filled with } \\
\text { rainwater and/or condensation water. A grab } \\
\text { sample of the water was collected (the entire } \\
\text { volume) and submitted for radiological and } \\
\text { total metals analysis. } \\
\text { A fragment of raschig ring was collected } \\
\text { from the south port and submitted for } \\
\text { composition analysis. }\end{array}$ \\
\hline 2 & $\begin{array}{l}\text { Grab sample of the yellow residue; submit } \\
\text { for microbiological evaluation for } \\
\text { identification and/ or confirmation of } \\
\text { fungal structures via direct examination. }\end{array}$ & $\begin{array}{l}\text { The yellow residue was sampled as planned } \\
\text { and analyzed by two laboratories to identify } \\
\text { fungal structure. Neither laboratory } \\
\text { produced evidence the material is } \\
\text { biological, so the remaining sample was } \\
\text { submitted for composition analysis. Solids } \\
\text { have been identified as iron sulfate crystals. }\end{array}$ \\
\hline 3 & $\begin{array}{l}\text { Grab sample of intact rubber liner, residues } \\
\text { piled at the low point of the tank, and any } \\
\text { liquids to be analyzed, if encountered. }\end{array}$ & $\begin{array}{l}\text { All of the liner material, with exception of a } \\
\text { thin film presumed to be adhesive, appeared } \\
\text { to have decomposed and accumulated in } \\
\text { chunks at the bottom of the tank (the } \\
\text { residues). No liquids were present, but the } \\
\text { decomposed liner contains visible mercury } \\
\text { which dripped from the material during } \\
\text { sampling. The grab sample of the former } \\
\text { liner was submitted for a full suite analysis }\end{array}$ \\
\hline 4 & $\begin{array}{l}\text { Grab sample of intact rubber liner, residues } \\
\text { piled at the low point of the tank, and any } \\
\text { liquids to be analyzed, if encountered. }\end{array}$ & $\begin{array}{l}\text { Based on safety concerns and events } \\
\text { surrounding Tank } 3 \text {, sampling of the Tank } 4 \\
\text { liner was not attempted. }\end{array}$ \\
\hline 5 & $\begin{array}{l}\text { Grab sample of the residue at the bottom of } \\
\text { the tank and hold under custody awaiting } \\
\text { analysis decision by the stakeholders. }\end{array}$ & $\begin{array}{l}\text { Residue sample was collected as planned. } \\
\text { The sample volume was minimal and very } \\
\text { low density. The samples were submitted } \\
\text { for a full suite analysis }{ }^{a} \text { per stakeholder } \\
\text { consensus. }\end{array}$ \\
\hline
\end{tabular}

${ }^{a}$ Solids Full Suite = TCLP mercury, TCLP metals, Cs-137, Co-60, and Th-234 via gamma spectroscopy, isotopic uranium by ICPMS (total U, U-233/234, U-235/236, and U-238), isotopic thorium (Th-228, 229, 230, and 232), isotopic plutonium (Pu-238, 239/240), Am-241, Np-237, Sr-90, and Tc-99, PCBs, TCLP VOAs, TCLP SVOAs, TCLP pesticides, TCLP herbicides, total mercury, total metals, total VOAs, total SVOAs, total pesticides, and total herbicides 


\section{REFERENCES}

Abelquist, Eric 2001. Decommissioning Health Physics - A Handbook for MARSSIM Users. ISBN 075030761 7. Institute of Physics Publishing, London.

ORAU 2012. Project-Specific Plan for Characterization of the Five Tanks Located near the Old Salvage Yard at the Y-12 National Security Complex, Oak Ridge, Tennessee. DCN: 4858-PL-01-2. Prepared by Oak Ridge Associated Universities for the U.S. Department of Energy—Environmental Management, May. 